of the limiting moduli and the static dielectric constant, phenomenological theories of mechanical and dielectric, relaxation, and molecular theories of relaxation including an account of sccondary relaxations in solids. 'Two useful chapters on experimental methods, mechanical and dielectric, conclude the first two-fifth of the book. The rest is dovoted to chapters on results obtained on individual classes of polymers, including methacrylate and related polymers; polyvinyl esters and related polymers; hydrocarbon polymers; halogen polymers; polyamides and polyurethanes; polyesters and polycarbonates; and, finally, oxide polymers. A reference section containing moro than 800 references in alphabetical sequence, many of recent origin, an author index and subject index complete the publication.

The overall impression is of an authoritative account, agreeably printed and adequately supplemented with tables and figures-and not one spring or dashpot in sight-presented with a textual precision which permits a high content of detailed information. Porhaps bocauso of this, readers from one discipline may wish for a little elaboration on some parts which will be sufficient for those from another, and yet there will be no difficulty for the serious reader in seeking appropriate information, whether it bo theorotical or experimental. Here it should be pointed out, as the authors admit, that the subject matter is such that it will be of more immediate intcrest to the researcher rather than to, say, the practising engineer. Nevertheless, herein lie many of the explanations for the often maligned properties of polymers which havo beon used in the wrong context, and to this end I feel that the book, or its contents, may profitably be reported outside the research laboratory. This is a valuable publication and, although there may be one or two books it will not supplant, except in date, there are many accounts it will, and it is therefore strongly recommonded both as a textbook and reference book for the serious reader and researcher in polymer science.

R. P. SHELdoN

\section{LAYERED ROCKS}

\section{Layered Igneous Rocks}

By L. R. Wager and G. M. Brown. Pp. xv+588. (Edinburgh and London : Oliver and Boyd, Ltd., 1968.) 168s. net.

THE phenomenon of layering in igneous rocks has fascinated petrologists for many years and the name of Professor Wager has been associated with the subject, in particular with the Skaergaard Intrusion of East Greenland, for sorne thirty of them. It is fortunate that he had completed his contribution to this book before his sudden death in 1965 and that Professor Brown was able to carry the book to publication.

The first part, written by Professor Wager, gives a very detailed account of the Skaergaard Intrusion which serves as a basis for comparison with the other layered complexes. The account is systematic and commencos with a general introduction to the characteristic features of the complex. Having done this, the minerals and the rocks composing tho layored series are described. The chemistry is given meticulous coverage and equal attention is paid to the mechanism of differentiation of the layering. While putting forward a theory, the authors do not agree that an explanation for ono locality may necessarily satisfy another, and point out (page 338) that "No single theory is capable of explaining, for all layered intrusions, the origin of a feature such as rhythmic layering, bccausc, despite overall similarities, the details differ from one intrusion to another'.

The second part of the book, written by Professor Brown, is devoted to the other layered complexes of the world and in particular to the Bushveld, Stillwater and
Rhum Intrusions. In each case the treatment is the same, which makes comparison easy. The form of the intrusion is described together with an account of its minerals present; the principal subdivisions of the intrusions are discussed and finally the crystal history is given. In the case of the Bushveld, this is probably the most up to date general account since Hall's memoir of 1924. In all cases reference is made back to Skaergaard and points of similarity and dissimilarity are noted.

Other types of basic layered intrusions described include the Cuillins of Skye, Kap Fdvard Holm, Fast Greenland; Duluth, Minnesota; and the Great Dyke of Southern Rhodesia. Described in less detail are twenty-nine smaller layered and fractionatod intrusions, which are grouped by continents. They include Ardnamurchan, the Lizard and Dawros from the British Isles, several examples from North Amorica and Africa and three from Russia. A short chapter is included on Differentiated Sills and there is also one dealing with layering in syenites and granites.

This is a very comprehensive work - a compendium of layered intrusions in fact-which has been brought together in one volume for the first time. The detail is such that it will be of most uso to the advanced student and postgraduate, although students of even first year level may derive benefit from reading the first and last chapters on general aspects of layering. It will be, and deserves to be, a classic textbook and it is a fitting tribute to Professor Wager's work.

J. R. V. Brooks

\section{CELLS IN PAPERBACK}

\section{The Cellular Role of Macromolecules}

(Series in Undorgraduate Biology, Vol. 2.) By P. H. Jellinck. Pp. 117. (Glenview, Ill.: Scott, Foresman and Company, 1967.) \$2.25.

THere have been considerable changes in the teaching of biology recently, both at school and in the university, and thero is a demand for suitable books particularly at the elementary level. Publishers have met this need with textbooks of wide coverage and uneven quality, which are often characterized by redundant illustration. There has also been a tendency for the production of paperback series which, while certainly no cheaper in aggregate, allow individual selections. A nurrower coverage also provides the opportunity for two essential features of any clementary monograph which is to interest and educate a student: an informed selection from the vast amount of material available, and a coherent view of the subject by the author.

These desirable but elusive features are not always found in every volume of a series. "The cellular role of macromolecules" is a large subject and may be difficult to cover adequately, but this book makes the attempt. It begins with the description of various cells, then covers dynamic aspects of biological systems, before proceeding to a discussion of intermediary metabolism, biosynthesis and regulatory mechanisms.

Unfortunately it is not always very accurato. For example, Gurdon's work on nuclear transplantation indicales a position very different from that of Briggs's and King's. Transeription of RNA from one strand only of the DNA double helix clearly was not first shown from the poly dAT experiment quoted, nor does the evidence quoted show that transcription occurs "within the minor groove" of the DNA helix.

The book is probably the better for not being lavishly illustrated, although the whole page diagram of the reactions involved in lipid biosynthesis would not be very clear to an elementary student and certainly fails to cornpensate for the two short paragraphs on the subject. Holley's work on transfer-RNA sequence is mentioned, but no comment is made on the secondary structure, with 